\title{
The Effects of Biochar and Chicken Manure Application on Red Ginger (Zingiber Officinale Rosc.) Growth and Yield of Semi Paludiculture in Tropical Peatlands
}

\author{
Karuna Mardiansyah, Aswin Usup, and Erina Riak Asie \\ Department of Agronomy, Faculty of Agriculture, University of Palangka Raya \\ Correspondence email: karunamardiansyah@gmail.com
}

\begin{abstract}
The research was conducted to determine the influence of growth and yield of red ginger plants by applying the combination of biochar palm oil and chicken manure in a semi-paludiculture planting system on peatland. The design used in this study is the Completely Randomized Design (CRD) with $4 \times 4$ factors and with a three repetitions factor. The first treatment factors are oil palm shell biochar with control treatment, $5 \mathrm{t} \mathrm{ha}^{-1}, 10 \mathrm{t}$ $\mathrm{ha}^{-1}$ and $15 \mathrm{t} \mathrm{ha}^{-1}$ and the second factor is chicken manure with control treatment, $5 \mathrm{t} \mathrm{ha}^{-1}, 10 \mathrm{tha}^{-1}$ and $15 \mathrm{t}$ $\mathrm{ha}^{-1}$. The research was conducted in Tanjung Taruna Village, Jabiren Raya Sub-district, Pulang Pisau Regency. The research was conducted from December 2018 until April 2019. The results showed that the interaction occurred in both factors, on the plant variable's height and the highest yield from the introduction of chicken manure $10 \mathrm{t} \mathrm{ha}^{-1}$ and the biochar $15 \mathrm{t} \mathrm{ha}^{-1}$. The interaction of biochar palm oil shells on growth and yield of ginger plants only occur in plant variable height and the samplings at 8, 10, and 14 weeks after planting. While the chicken manure has real effect on ginger plants' growth and yield in all observation variables.
\end{abstract}

Keywords: biochar, chicken manure, red ginger, semi-paludiculture.

\section{INTRODUCTION}

Red ginger (Zingiber officinale Rosc.) is a spice plant traded in the world and exported in the form of fresh ginger, dried ginger, processed ginger, and essential oil (Rapelia, 2012). The more rapid activities of the modern, traditional medicine industry and other industries that have sprung up using ginger as raw material have caused the demand for this commodity to tend to increase from year to year (Pribadi, 2009). The survey results from the Ministry of Agriculture (2008) in 7 (seven) main provinces for the development of the traditional medicine industry show that the volume of ginger needs for the industry reaches more than 47,000 tons per year and does not include the needs of the traditional medicine industry so that Indonesia still imports ginger from China. Indonesia has the largest peatlands among tropical countries, namely \pm 21 million ha, which are spread mainly in Sumatra, Kalimantan, and Papua, which can develop red ginger. However, due to the very high variability in land quality, both in terms of peat thickness, maturity, and fertility, not all peatlands are suitable for agricultural use. Central Kalimantan contains \pm 3 million ha of peatlands, or about $13.5 \%$ of all peatlands in Indonesia, with an average thickness of 3 meters (Konsorsium Central Kalimantan Peatlands Project, 2008). Utilization of peat land for agricultural land is quite difficult and requires proper handling to not damage the peat itself.

Therefore, the use of peat in semi-paludiculture is one solution. Paludiculture is defined as the sustainable production of biomass in wet or wetted peat conditions (Wichtmann and Joosten, 2007), and at least three things are related, namely the benefits of paludicultural ecosystem services, the hydrological conditions of peatlands, and the selection of vegetation for planting, especially in tropical areas ( Tan et al., 2021). Semi-paludiculture is a technique of modifying the environment by not changing and or destroying land conditions but can be used for cultivation. Semipaludiculture has the principle of reducing the level of peat damage and increasing the potential yield of plants cultivated on peat soil, with improved media, including the use of biochar and manure. Biochar or black carbon can overcome some limitations and provide additional options for soil management. Biochar is more effective at holding nutrient 
availability for plants than other organic materials such as leaf litter, compost, or manure. Biochar can also withstand $\mathrm{P}$, which cannot be retained by ordinary organic matter (Jambi Agricultural Technology Research Institute, 2015). One of the agricultural wastes that can be processed into biochar is oil palm shell. The potential of oil palm shells as biochar for soil improvement is quite large, given the large production and area of oil palm plantations in Central Kalimantan. The area of oil palm land in Central Kalimantan is 1,142,004 ha, with 3,572,982 tonnes in 2015 (Directorate General of Plantation, 2016). While manure has natural properties and does not damage the soil, it provides macro and micro elements. It also increases the soil's ability to hold water, increase soil microbiological activity and cation exchange capacity and improve soil structure. Chicken manure contributes to nutrients that can meet plant growth because chicken manure contains higher nutrients than other manure. Besides, chicken manure has a reasonably good effect on peat soil fertility because it contains complete nutrients (macro and micro), and the microorganisms in it can break down peat so that nutrients in peat such as $\mathrm{P}$ are easily available to plants (Yuliana et al., 2015). This research aimed to study the interaction between biochar and chicken manure and its effect on the growth and yield of ginger by semipaludiculture in peat soils.

\section{MATERIALS AND METHODS}

The research was carried out in December 2018-April 2019. In the village of Tanjung Taruna, District Jabiren Raya, District Pulang Pisau, Province of Central Kalimantan. The material used in this research is a sack with a capacity of $50 \mathrm{~kg}$, oil palm shell biochar, manure broiler, dolomite, Urea, SP36, $\mathrm{KCl}$, Dhitane M-45, Grow Quick, peat soil, and seeds of red ginger.

The design applied in this study was a completely randomized design (CRD) with a $4 \times 4$ factor pattern with 3 (three) replications. The first factor is biochar with control treatment, $5 \mathrm{t} \mathrm{ha}^{-1}, 10 \mathrm{t} \mathrm{ha}^{-1}$ and $15 \mathrm{t} \mathrm{ha}^{-1}$. The second factor was chicken manure with control treatment, $5 \mathrm{t} \mathrm{ha}^{-1}, 10 \mathrm{tha}^{-1}$ and $15 \mathrm{t} \mathrm{ha}^{-1}$, so 16 treatment combinations were obtained and 3 replications so that a total of 48 experimental units were obtained.

Maintenance is carried out by several methods, including:

a. Watering is done in the nursery and after planting in the field, the plants are watered in early April because of the low rainfall intensity;

b. Embroidering is done to replace plants that do not grow or plants that grow stunted. Stitching is done when the plants are 3 weeks after planting. Insert plants come from the same seeds that have been prepared in advance;

c. Humping is done by making a mound of soil around the plant. Filling begins 3 weeks after transplanting when clumps have formed, so that the rhizome is always covered with soil. Another goal is that drainage will always be maintained. Weeding is done manually by pulling out weeds that grow around the sacks;

d. Fertilization is done by applying SP36 fertilizer at planting time, Urea fertilizer when the plants are 4 weeks old after planting and $\mathrm{KCl}$ fertilizer is given when the plants are $10 \mathrm{WAP}$, with a dose of Urea $300 \mathrm{~kg} \mathrm{ha}^{-1}$, SP36 $200 \mathrm{~kg} \mathrm{ha}^{-1}, \mathrm{KCl} 200 \mathrm{~kg}$ $\mathrm{ha}^{-1}$;

e. Pest and disease control is carried out by spraying the fungicide Dithane M-45;

f. Harvesting is done when the ginger plant is four months after planting by washing the ginger and drying it.

Observational variables, the observed variables are as follows:

a. Plant height $(\mathrm{cm})$, measurements are taken from the base of the stem to the tip of the longest leaf and performed at the age of 6 , $8,10,12,14$ and 16 weeks after planting with intervals of 2 weeks. Measurement of plant height is carried out using a measuring device.

b. Number of tillers (stems), observations are made by counting the total number of tillers in the sack. Performed at the age of $6,8,10,12,14$ and 16 weeks after planting with intervals of 2 weeks.

c. Fresh Weight of Rhizome (g), the calculation of fresh weight of ginger rhizome is done at the end of the 
observation by weighing the amount of ginger that has been dried.

d. Plant dry weight (g), the measurement of plant dry weight was carried out by means of oven samples at $70^{\circ} \mathrm{C}$ for 48 hours, then weighed. Samples were taken at harvest time.

Data analysis, the results of the observations were analyzed using the $\mathrm{F}$ test (analysis of variance) at the $5 \%$ confidence level. If there is a difference between treatments, then a further test is carried out using the mean Honest Significant Difference (HSD) test at the 5\% level.

\section{RESULTS AND DISCUSSION}

\section{Plant Height}

The effect of biochar and chicken manure is presented in Table 1. Based on Table 1, it appears that the provision of oil palm shell biochar with chicken manure can significantly increase the height of ginger plants at all ages of observation. The lowest plant height was obtained in the control treatment while increasing the chicken manure and biochar dose was followed by an increase in plant height. This happens because of the function of chicken manure, which increases plants' absorption capacity in binding nutrients, which can increase soil fertility. Therefore, the roots will more easily absorb the nutrients contained in the soil. Widiowati (2004) states that nutrients absorbed by plant roots are used to increase plant height growth.

Meanwhile, oil palm shell biochar acts as an ameliorant to increase soil $\mathrm{pH}$ and has high water retention capacity (Ardiyani et al, 2015). Asie et al. (2013) stated that Application chicken manure increased the growth and yield of ginger on plant height variables, a number of tillers, leaf area, and fresh ginger rhizome weight. There is a very significant effect on plant height because chicken manure can improve soil physical, chemical and biological properties to maintain, improve and increase soil fertility. Setyamidjaja (1986) in Afandi (2018) states that poultry fed with protein and mineral feed will produce manure that is high in nitrogen and mineral content. The results of Bella \& Pradika's research (2018) state that the use of oil palm shell biochar also shows an increase in the height of the red ginger plant. This is because biochar releases nutrients slowly to plants. So that nutrients will remain available for up to one growing season without having to provide them intensively. The same thing was reported by Putri et al. (2017) that Application biochar can increase soil $\mathrm{pH}$, Corganic, total $\mathrm{N}$, P-available, $\mathrm{K}$ exchange, flowering age, plant height, canopy dry weight, and $\mathrm{N}$ and $\mathrm{P}$ uptake. Solaiman \& Anwar (2015) state that biochar's alkalinity is one of the factors that biochar has potential as lime. In addition, biochar can also bind $\mathrm{C}$-organic in the soil to remain stable and not easily decomposed by microorganisms.

Table 1. Average of red ginger plant height (cm clump-1) at age $6,8,10,12,14$ and 16 WAP

\begin{tabular}{|c|c|c|c|c|c|}
\hline \multirow{2}{*}{ Age } & \multirow{2}{*}{$\begin{array}{l}\text { Chicken Manure } \\
\text { (ton ha-1) }\end{array}$} & \multicolumn{4}{|c|}{ Biochar (ton ha-1) } \\
\hline & & 0 & 5 & 10 & 15 \\
\hline \multirow{4}{*}{$6 \mathrm{WAP}$} & 0 & $21.17 \mathrm{a}$ & $25.50 \mathrm{a}$ & $22.17 \mathrm{a}$ & $22.50 \mathrm{a}$ \\
\hline & 5 & $52.33 \mathrm{de}$ & $40.17 \mathrm{~b}$ & $46.50 \mathrm{bcd}$ & 49.17 cde \\
\hline & 10 & $51.50 \mathrm{de}$ & $54.50 \mathrm{e}$ & $53.50 \mathrm{de}$ & $54.83 \mathrm{e}$ \\
\hline & 15 & $40.83 \mathrm{~b}$ & $44.23 \mathrm{bc}$ & $41.17 \mathrm{~b}$ & $40.50 \mathrm{~b}$ \\
\hline & BNJ $\alpha 0.05=7.23$ & & & & \\
\hline \multirow{4}{*}{$8 \mathrm{WAP}$} & 0 & $26.43 \mathrm{a}$ & $27.83 \mathrm{a}$ & $27.00 \mathrm{a}$ & $26.67 \mathrm{a}$ \\
\hline & 5 & $61.03 \mathrm{cde}$ & $47.57 \mathrm{~b}$ & $58.50 \mathrm{cde}$ & $56.33 \mathrm{~cd}$ \\
\hline & 10 & $61.93 \mathrm{de}$ & $63.50 \mathrm{e}$ & 60.83 cde & $62.07 \mathrm{de}$ \\
\hline & 15 & 59.60 cde & $59.50 \mathrm{cde}$ & 58.83 cde & $55.33 \mathrm{c}$ \\
\hline & BNJ $\alpha 0.05=6.00$ & & & & \\
\hline \multirow{4}{*}{$10 \mathrm{WAP}$} & 0 & $28.33 \mathrm{a}$ & $30.50 \mathrm{a}$ & $30.17 \mathrm{a}$ & $30.50 \mathrm{a}$ \\
\hline & 5 & $65.17 \mathrm{~cd}$ & $51.17 \mathrm{~b}$ & $62.83 \mathrm{~cd}$ & $63.27 \mathrm{~cd}$ \\
\hline & 10 & $68.50 \mathrm{~d}$ & $68.50 \mathrm{~d}$ & $69.57 \mathrm{~d}$ & $66.00 \mathrm{~d}$ \\
\hline & 15 & $66.27 \mathrm{~d}$ & $65.50 \mathrm{~cd}$ & $66.33 \mathrm{~d}$ & $58.50 \mathrm{c}$ \\
\hline
\end{tabular}




\begin{tabular}{|c|c|c|c|c|c|}
\hline & BNJ $\alpha 0.05$ & & & & \\
\hline \multirow{4}{*}{$12 \mathrm{WAP}$} & 0 & $30.17 \mathrm{a}$ & $32.50 \mathrm{a}$ & $32.33 \mathrm{a}$ & $33.07 \mathrm{a}$ \\
\hline & 5 & $72.33 \mathrm{~cd}$ & $57.83 \mathrm{~b}$ & $70.10 \mathrm{~cd}$ & $70.67 \mathrm{~cd}$ \\
\hline & 10 & $71.63 \mathrm{~cd}$ & $74.53 \mathrm{~d}$ & $75.33 \mathrm{~d}$ & $74.83 \mathrm{~d}$ \\
\hline & 15 & $70.00 \mathrm{~cd}$ & $70.00 \mathrm{~cd}$ & $71.17 \mathrm{~cd}$ & $62.50 \mathrm{bc}$ \\
\hline \multicolumn{6}{|c|}{ BNJ $\alpha 0.05=10.91$} \\
\hline \multirow{4}{*}{14 WAP } & 0 & $36.50 \mathrm{a}$ & $40.33 \mathrm{a}$ & $40.83 \mathrm{a}$ & $40.27 \mathrm{a}$ \\
\hline & 5 & $78.67 \mathrm{c}$ & $65.17 \mathrm{~b}$ & $82.50 \mathrm{c}$ & $77.73 \mathrm{bc}$ \\
\hline & 10 & $80.27 \mathrm{c}$ & $83.17 \mathrm{c}$ & $82.17 \mathrm{c}$ & $83.17 \mathrm{c}$ \\
\hline & 15 & $76.83 \mathrm{bc}$ & $76.83 \mathrm{bc}$ & $81.50 \mathrm{c}$ & $71.67 \mathrm{bc}$ \\
\hline \multicolumn{6}{|c|}{ BNJ $\alpha 0.05=12.62$} \\
\hline \multirow{4}{*}{$16 \mathrm{WAP}$} & 0 & $40.50 \mathrm{a}$ & $43.83 \mathrm{a}$ & $41.73 \mathrm{a}$ & $41.77 \mathrm{a}$ \\
\hline & 5 & $81.80 \mathrm{bc}$ & $68.17 \mathrm{~b}$ & $85.17 \mathrm{c}$ & $80.50 \mathrm{bc}$ \\
\hline & 10 & $83.50 \mathrm{c}$ & $86.50 \mathrm{c}$ & $85.60 \mathrm{c}$ & $86.90 \mathrm{c}$ \\
\hline & 15 & $82.50 \mathrm{bc}$ & $80.33 \mathrm{bc}$ & $86.67 \mathrm{c}$ & $75.67 \mathrm{bc}$ \\
\hline
\end{tabular}

$\mathrm{BNJ} \alpha 0.05=14.47$

Note: The numbers followed by the same letters in the row and column and the same age show no significant difference in the $5 \%$ BNJ test

\section{Number of Tillers}

The effect of treatment on the number of tillers is presented in Table 2. Based on Table 2, the results of the average number of tillers of ginger at the age of 8,10 and 14 WAP (weeks after planting), there was an interaction effect between chicken manure and biochar, while the provision of oil palm shell biochar to plants aged 6,12 and 16 WAP did not have a significant effect on the number of red ginger tillers. This is thought to be due to the high rainfall at the time of the study so that the growing medium for ginger plants was flooded. Stagnant water affects physiological and biochemical processes such as respiration, soil permeability, absorption of water and nutrients, and $\mathrm{N}$ embedding. Besides, it can cause death to roots due to root rot. Subbaiah et al. (2000) in Rahman (2016) stated that waterlogged plants resulted in decreased root growth caused by an increase in the hormone ethylene under hypoxic/anoxic conditions. This also triggers tissue death in the plant roots and allows the process of root tip death. Besides, the water holding capacity of biochar is quite large so that the infiltration power of the planting medium will decrease when it is inundated. The administration of biochar is thought not to have a direct effect on red ginger plants, Mawardiani et al. (2013) stated that land that contains biochar, its nutrients are released slowly so that it can be used optimally by plants. Saputra $e t$ al. (2016) reinforced this statement, which states that Application biochar with a combination of inorganic fertilizers will be more efficient if it uses a long or gradual time. The use of chicken manure had a significant effect on the number of tillers of ginger at 6,8 , $10,12,14$ and 16 WAP. It was proven that Application chicken manure could increase the number of tillers of red ginger plants. Yuliana et al. (2015) stated that providing sufficient nutrients will increase the number of polybag ${ }^{-1}$ tillers to increase the number of rhizome tillers, which can increase the production of fresh rhizomes. Based on the test for the average number of red ginger tillers, the provision of chicken manure increased the number of tillers. This is presumably because chicken manure can provide sufficient nutrients for the growth and development of ginger rhizomes.

Table 2. Number of tiller of red ginger on $6,8,10,12,14$ and 16 WAP. 


\begin{tabular}{|c|c|c|c|c|c|c|}
\hline \multirow{2}{*}{ Ages } & \multirow{2}{*}{$\begin{array}{c}\text { Chicken } \\
\text { Manure (ton } \\
\text { ha }^{-1} \text { ) }\end{array}$} & \multicolumn{3}{|c|}{ Biochar (ton ha-1) } & \multicolumn{2}{|c|}{ Average } \\
\hline & & 0 & 5 & 10 & 15 & \\
\hline \multirow{5}{*}{$6 \mathrm{WAP}$} & 0 & 4.33 & 3.33 & 2.33 & 2.00 & $3.00 \mathrm{a}$ \\
\hline & 5 & 3.00 & 4.33 & 4.00 & 4.33 & $3.92 \mathrm{a}$ \\
\hline & 10 & 4.67 & 3.67 & 6.00 & 4.67 & $4.75 \mathrm{~b}$ \\
\hline & 15 & 4.67 & 5.00 & 3.67 & 4.67 & $4.50 \mathrm{~b}$ \\
\hline & Average & 4.17 & 4.08 & 4.00 & 3.92 & \\
\hline \multicolumn{7}{|c|}{ HSD $\alpha 0.05=1.26$} \\
\hline \multirow{5}{*}{$8 \mathrm{WAP}$} & 0 & $5.33 \mathrm{ab}$ & $4.67 \mathrm{a}$ & $6.33 \mathrm{abc}$ & $4.67 \mathrm{a}$ & 5.25 \\
\hline & 5 & $5.33 \mathrm{ab}$ & 9.00 cde & 8.33 bcde & $6.67 \mathrm{abcd}$ & 7.33 \\
\hline & 10 & $11.67 \mathrm{e}$ & $6.67 \mathrm{abcd}$ & $9.00 \mathrm{cde}$ & $10.33 \mathrm{e}$ & 9.42 \\
\hline & 15 & $10.00 \mathrm{de}$ & $8.67 \mathrm{bcde}$ & $10.00 \mathrm{de}$ & $9.67 \mathrm{cde}$ & 9.58 \\
\hline & Average & 8.08 & 7.25 & 8.42 & 7.83 & \\
\hline \multicolumn{7}{|c|}{ HSD $\alpha 0.05=3.53$} \\
\hline \multirow{5}{*}{$10 \mathrm{WAP}$} & 0 & $6.33 \mathrm{ab}$ & $6.00 \mathrm{a}$ & 9.33 abcde & $8.00 \mathrm{abc}$ & 7.42 \\
\hline & 5 & $9.00 \mathrm{abcd}$ & $14.33 \mathrm{def}$ & $15.00 \mathrm{def}$ & 15.33 ef & 13.42 \\
\hline & 10 & $14.67 \mathrm{def}$ & 10.33 abcde & 12.00 abcdef & 15.33 ef & 13.08 \\
\hline & 15 & $16.67 \mathrm{f}$ & $14.00 \mathrm{cdef}$ & 12.33 abcdef & $12.67 \mathrm{cdef}$ & 13.92 \\
\hline & Average & 11.67 & 11.17 & 12.17 & 12.83 & \\
\hline \multicolumn{7}{|c|}{ HSD $\alpha 0.05=6.28$} \\
\hline \multirow{5}{*}{12 WAP } & 0 & 7.33 & 7.33 & 10.67 & 9.33 & $8.67 \mathrm{a}$ \\
\hline & 5 & 13.00 & 20.33 & 22.33 & 22.00 & $19.42 \mathrm{~b}$ \\
\hline & 10 & 18.33 & 21.00 & 18.00 & 24.33 & $20.42 \mathrm{~b}$ \\
\hline & 15 & 23.67 & 20.67 & 20.33 & 16.67 & $20.33 \mathrm{~b}$ \\
\hline & Average & 15.58 & 17.33 & 17.83 & 18.08 & \\
\hline & HSD $\alpha 0.05=$ & & & 4.45 & & \\
\hline \multirow{5}{*}{14 WAP } & 0 & $11.00 \mathrm{a}$ & $11.33 \mathrm{a}$ & $18.00 \mathrm{ab}$ & $17.00 \mathrm{ab}$ & 14.33 \\
\hline & 5 & $20.00 \mathrm{abc}$ & $24.67 \mathrm{abc}$ & $28.00 \mathrm{bc}$ & $28.67 \mathrm{bc}$ & 25.33 \\
\hline & 10 & $27.00 \mathrm{bc}$ & $29.67 \mathrm{bc}$ & $24.00 \mathrm{abc}$ & $29.67 \mathrm{bc}$ & 27.58 \\
\hline & 15 & $33.33 \mathrm{c}$ & $26.67 \mathrm{abc}$ & $26.67 \mathrm{abc}$ & $18.00 \mathrm{ab}$ & 26.17 \\
\hline & Average & 22.83 & 23.08 & 24.17 & 23.33 & \\
\hline \multirow{7}{*}{$16 \mathrm{WAP}$} & HSD $\alpha 0.05=$ & .95 & & & & \\
\hline & 0 & 12.33 & 14.33 & 21.67 & 18.67 & $16.75 \mathrm{a}$ \\
\hline & 5 & 23.67 & 29.33 & 31.00 & 32.67 & $29.17 \mathrm{~b}$ \\
\hline & 10 & 28.67 & 31.67 & 27.33 & 32.33 & $30.00 \mathrm{~b}$ \\
\hline & 15 & 35.67 & 30.67 & 29.67 & 30.00 & $31.50 \mathrm{~b}$ \\
\hline & Average & 25.08 & 26.50 & 27.42 & 28.42 & \\
\hline & HSD $\alpha 0.05$ & .04 & & & & \\
\hline
\end{tabular}

Note: The numbers followed by the same letters in the same row and column and the same age show no significant difference in the $5 \%$ HSD test

\section{Fresh Rhizome Weight (g)}

The effect of treatment on fresh rhizome weight is presented in Table 3. The results of the average test of ginger rhizome fresh weight showed that the dose of chicken manure had a significant effect on the yield of ginger. The results of the analysis of the nutrient content of chicken manure showed that the elements N, P and $\mathrm{K}$ were higher than biochar. Application of chicken manure with a dose of $10 \mathrm{t} \mathrm{ha}^{-1}$ was significantly different from chicken manure treatment at a dose of $15 \mathrm{t} \mathrm{ha}^{-1} .5 \mathrm{t} \mathrm{ha}^{-1}$ and without Application chicken manure (control). The heaviest average fresh weight of ginger clump $^{-1}$ was in the provision of chicken manure at a dose of $10 \mathrm{tha}^{-1}$ with an average weight of $131.31 \mathrm{~g} \mathrm{clump}^{-1}$ followed by $5 \mathrm{t} \mathrm{ha}^{-1}$ treatment 
with an average weight of $97.02 \mathrm{~g} \mathrm{clump}^{-1}$ was then followed by a treatment dose of $15 \mathrm{t} \mathrm{ha}^{-1}$ with an average weight of $92.87 \mathrm{~g} \mathrm{clump}^{-1}$ and without treatment with an average weight of $33.91 \mathrm{~g} \mathrm{clump}^{-1}$. This shows that chicken manure can supply sufficient nutrients for red ginger plants. Yuliana et al. (2015) stated that Application chicken manure can increase the growth and yield of ginger, this is following the results of his research which showed that Application chicken manure increased the wet weight of the rhizomes, with a difference of $28.18 \%$ higher than the wet weight of rhizomes with fertilizer. cowshed. Likewise the research results of Marlina et al. (2015) Application chicken manure at a dose of $10 \mathrm{tha}^{-1}$ was able to increase the amount of dry weight of pods, percentage of pods, weight of seeds evenly produced in plots of peanut plants. Phosphorus is absorbed by plants in the form of $\mathrm{H} 2 \mathrm{PO}_{4}$ and $\mathrm{HPO}_{4}{ }^{2-}$, which is very important in the energy transfer process in plants, regulates the processes of photosynthesis, respiration and cell division, and affects the ripening period of seeds and fruits. Potassium is absorbed by plants in the form of $\mathrm{K}^{+}$cations, which play a role in forming and transferring carbohydrates in plants (Handayanto et al., 2016). With good photosynthesis and balanced with the translocation of photosynthate to a large part of the rhizome, it will cause the rhizome's fresh weight to increase. Misnadeh et al. (2019) stated that Application chicken manure fertilizer at a dose of $2.80 \mathrm{~kg} \mathrm{plot}^{-1}$ equivalent to $20 \mathrm{tha}^{-1}$ can increase the growth and yield of ginger on alluvial soil.

\section{Plant Dry Weight}

chicken manure. Plant growth and development are strongly influenced by macro

Table 3. Fresh Weight of Ginger Plant Rhizome per Clump.

\begin{tabular}{|c|c|c|c|c|c|}
\hline \multirow{2}{*}{$\begin{array}{l}\text { Chicken Manure } \\
\quad\left(\text { ton } \mathrm{ha}^{-1}\right)\end{array}$} & \multicolumn{4}{|c|}{ Biochar (ton ha-1) } & \multirow[t]{2}{*}{ Average } \\
\hline & 0 & 5 & 10 & 15 & \\
\hline 0 & 13.27 & 31.40 & 34.83 & 56.13 & $33.91 \mathrm{a}$ \\
\hline 5 & 91.77 & 95.47 & 83.77 & 117.07 & $97.02 \mathrm{~b}$ \\
\hline 10 & 129.77 & 163.60 & 126.87 & 105.00 & $131.31 \mathrm{c}$ \\
\hline 15 & 109.43 & 88.87 & 82.27 & 90.90 & $92.87 \mathrm{~b}$ \\
\hline Average & 86.06 & 94.83 & 81.93 & 92.28 & \\
\hline
\end{tabular}

Note: The numbers followed by the same letter in the same column show no significant difference in the 5\% HSD test

The effect of application of chicken manure and biochar fertilizers on the dry weight of plants is presented in Table 4. Application chicken manure at a dose of $15 \mathrm{t} \mathrm{ha}^{-1}$ gives the heaviest average yield of dry plant weight, namely $41.25 \mathrm{~g}$, followed by $10 \mathrm{t} \mathrm{ha}^{-1}$ with weight. an average of $40.80 \mathrm{~g}$, followed by treatment of 5 tons ha ${ }^{-1}$ with an average weight of $36.98 \mathrm{~g}$ and without treatment with an average weight of $10.25 \mathrm{~g}$. Plant dry weight shows the amount of biomass that plants can absorb, so the better the plant growth, the higher the dry weight.

The application of chicken manure $15 \mathrm{tha}^{-1}, 10$ $\mathrm{t} \mathrm{ha}^{-1}$, and $5 \mathrm{t} \mathrm{ha}^{-1}$ was not significantly different, but significantly different from the dry weight of ginger plants that were not given nutrients that are needed by plants, especially nitrogen, phosphorus and potassium which are very important for plant vegetative development. In the vegetative growth process of ginger, $\mathrm{N}, \mathrm{P}$ and $\mathrm{K}$ in chicken manure greatly affect the plant's dry weight, where the nutrient content of chicken manure is greater than that of biochar and peat soil. Research results from Taufik Atmaja et al. (2017) stated that Application chicken manure can increase the canopy and root dry weight of ginger plants, this is because chicken manure is able to supply $\mathrm{P}$ and $\mathrm{N}$ nutrients which play an important role in plant metabolism which includes cell division and development, energy transport, signal transduction, Macromolecular biosynthesis, photosynthesis and plant respiration. Alim et al. (2017) stated that the 
photosynthesis process in plants affects the plant's total dry weight. This statement is reinforced by Desiana et al. (2013), namely plant dry weight is the result of carbohydrate accumulation which is the result of photosynthetic activities, so that if the physiological processes that occur in plants go well and are supported by the application of efficient fertilization, it can increase plant dry weight.

Table 4. Dry Weight of Red Ginger per Plant Clump.

\begin{tabular}{cccccc}
\hline \multirow{2}{*}{ Chicken Manure (ton ha $\left.{ }^{-1}\right)$} & \multicolumn{5}{c}{ Biochar $\left(\right.$ ton $\left.\mathrm{ha}^{-1}\right)$} \\
\cline { 2 - 6 } & 0 & 5 & 10 & 15 & Average \\
\hline 0 & 5.41 & 7.40 & 12.27 & 15.90 & $10.25 \mathrm{a}$ \\
5 & 41.63 & 41.97 & 26.85 & 37.48 & $36.98 \mathrm{~b}$ \\
10 & 39.50 & 34.12 & 37.32 & 52.26 & $40.80 \mathrm{~b}$ \\
15 & 47.94 & 37.06 & 49.58 & 30.40 & $41.25 \mathrm{~b}$ \\
\hline Average & 33.62 & 30.14 & 31.51 & 34.01 & \\
\hline HSD $\alpha=0.05=16.40$ & \multicolumn{5}{c}{} \\
\hline
\end{tabular}

Note: The numbers followed by the same letters in the same row and column and the same age show no significant difference in the 5\% HSD test.

\section{CONCLUSION}

The interaction between biochar and chicken manure gave a different effect on the observation phase for each ginger plant growth variable. Biochar affected the growth and yield of ginger on the variable plant height and number of tillers at 8,10 and 14 WAP. The chicken manure application significantly affected the growth and yield of ginger on all treatment variables, with optimal results obtained from the provision of chicken manure at a dose of $10 \mathrm{tha}^{-1}$.

\section{REFERENCE}

Afandi, H. 2018. Aplikasi Solid, Tandan Kosong Kelapa Sawit dan Pupuk Kandang Ayam Pada Tanah Ultisol Untuk Budidaya Pakcoy (Brasica rapa L). Skripsi. Fakultas Pertanian Universitas Palangka Raya.

Alim, A.S., Sumarni, T. \& Sudiarso. 2017. Pengaruh Jarak Tanam dan defoliasi daun pada pertumbuhan dan hasil tanaman kedelai (Glycine max L.). Jurnal Produksi Tanaman. 5 (2) : 273280.

Ardiyani, R.R., Sutono dan S. Prijono. 2015. Perbaikan Retensi Air typic Kanhapludult Taman Bogo dan Pertumbuhan Tanaman Jagung Melalui
Pemberian Biochar Tempurung Kelapa Sawit. Jurnal Tanah dan Sumberdaya Lahan, Vol 2 (2) :199-209.

Asie, K.V., Saputera., Panupesi, H. \& Syahrudin. 2013. Pengaruh Pupuk Kandang Terhadap Beberapa Jenis Tanah Terhadap Pertumbuhan dan Hasil Jahe. Jurnal Agri Peat.14(1)

Atmaja, T., Damanik, M.M.B. \& Mukhlis. 2017. Pengaruh Pemberian Pupuk Kandang Ayam, Pupuk Hijau, dan Kapur $\mathrm{CaCO}_{3}$ Pada Tanah Ultisol Terhadap Pertumbuhan Tanaman Jagung. Jurnal Agroekoteknologi FP USU. 5(1): 208215

Balai Pengkajian Teknologi Pertanian Jambi. 2015. Teknologi Pembuatan dan Aplikasi Biochar dari Limbah Pertanian. Jambi.

Bella, S.E., \& Padrikal, R. 2018. Pemanfaatan Biochar Cangkang Kelapa Sawit Sebagai Substitusi Pupuk NPK Dalam Peningkatan Kualitas Lahan Pertanian. Journal of Applied Agricultural Science and Technology 2(1): 27-34.

Desiana, C., Banuwa, I.S., Evizal, R. \& Yusnaini, S. 2013. Pengaruh Pupuk Organik Cair Urin Sapi dan Limbah Tahu Terhadap Pertumbuhan Bibit 
Kakao (Theobroma cacao L.). Jurnal Agrotek Tropika. 1(1):113-119.

Direktorat Jenderal Perkebunan. 2016. Statistik Perkebunan Indonesia, Kelapa Sawit (Palm oil). Jakarta.

Handayanto, E., Maddarisna, N. \& Fiqri, A. 2016. Pengelolaan Kesuburan Tanah. Universitas Brawijaya Press. Malang.

Kementerian Pertanian. 2008. Budidaya Organik Tanaman Jahe. Balai Penelitian Tanaman Obat dan Aromatik Kementerian Pertanian. Bogor.

Konsorsium Central Kalimantan Peatlands Project (CKPP). 2008. Tanya dan Jawab Seputar Gambut di Asia Tenggara, Khususnya di Indonesia. Palangka Raya.

Marlina, N., Raden, I.S.A., Rosmiah., \& Lusdi, R.S. 2015. Aplikasi Pupuk Kandang Kotoran Ayam pada Tanaman Kacang Tanah (Arachis Hypogeae L). Jurnal Biosaintifika. 7 (2) :137-141.

Mawardiana., Sufardi \& Husen, E. 2013. Pengaruh Residu Biochar dan Pemupukan NPK Terhadap Dinamika Niterogen, Sifat Kimia Tanah Hasil Tanaman Padi (Oryza sativa L.) Musim Tanam Ketiga. Jurnal Manajemen Sumberdaya Lahan 2 (3) : 255-260

Misnadeh., Zulfita, D. \& Rahmidiyani. 2019. Pengaruh Pupuk Kotoran Ayam Terhadap Pertumbuhan Dan Hasil Jahe Pada Tanah Aluvial. Jurnal Sains Mahasiswa Pertanian UNTAN. 8 (1) : 19

Pribadi, R.E. 2009. Pasokan dan Permintaan Tanaman Obat Indonesia Serta Arah Penelitian dan Pengembangannya. Perspektif Vol. 8 No. 1 / Juni 2009. Hlm $52-64$.

Putri, V.S., Mukhlis \& Benny, H. 2017. Pemberian Beberapa Jenis Biochar untuk Memperbaiki Sifat Kimia Tanah Ultisol dan Pertumbuhan Tanaman Jagung. Jurnal Agroteknologi FP USU. 5 (4): 824-828.
Rakhman, R.Y. 2016. Respon Cekaman Genangan Periodik pada Beberapa Varietas Nicotiana tabacum. Tugas Akhir. Jurusan Biologi Fakultas Matematika dan Ilmu Pengetahuan Alam Institut Teknologi Sepuluh Nopember. Surabaya.

Rapelia. H. 2012. Analisis Pengaruh Beberapa Faktor terhadap Volume Ekspor Jahe (Zingiber officinale Rosc.) di Jawa Tengah. Skripsi. Fakultas pertanian, Universitas Sebelas Maret.

Saputra, R.T., Laila, R., Dedik B. \& Satria J.P. 2016. Serapan Nitrogen pada Pertumbuhan Padi (Oryza Sativa L.) dengan Pemberian Biochar di Lahan Rawa Lebak. Prosiding Seminar Nasional Lahan Suboptimal.Palembang : $186^{-1} 94$

Solaiman, Z.M. \& Anawar, H.M. 2015. Aplication of Biochars for Soil Constraints: Challenges and Solution. Pedosphere. 25 (5) : 631-638.

Tan, Z. D., M. Lupascu, L. S.Wijedasa. 2021. Paludiculture as a sustainable land use alternative for tropical peatlands: A review. Science of The Total Environment, Volume 753.

Wichtmann, W. and Joosten, H. 2007. Paludiculture: peat formation and renewable resources from rewetted peatlands. IMCG Newsletter, 3, pp.2428.

Widowati. 2004. Pengaruh Kompos Pupuk Organik Yang Dipekaya Dengan Bahan Mineral dan Pupuk Hayati Terhadap Sifat-Sifat Tanah, Serapan Hara dan Produksi Sayuran Organik. Laporan Proyek Penelitian Program Pengembangan Agribisnis. Balai Penelitian Tanah.

Yuliana., Rahmadani, E. \& Permanasari, I. 2015. Aplikasi Pupuk Kandang Sapi dan Ayam Terhadap Pertumbuhan dan Hasil Tanaman Jahe (Zingiber officinale Rosc.) di Media Gambut. Jurnal Agroteknologi. 5 (2): 37-42. 